
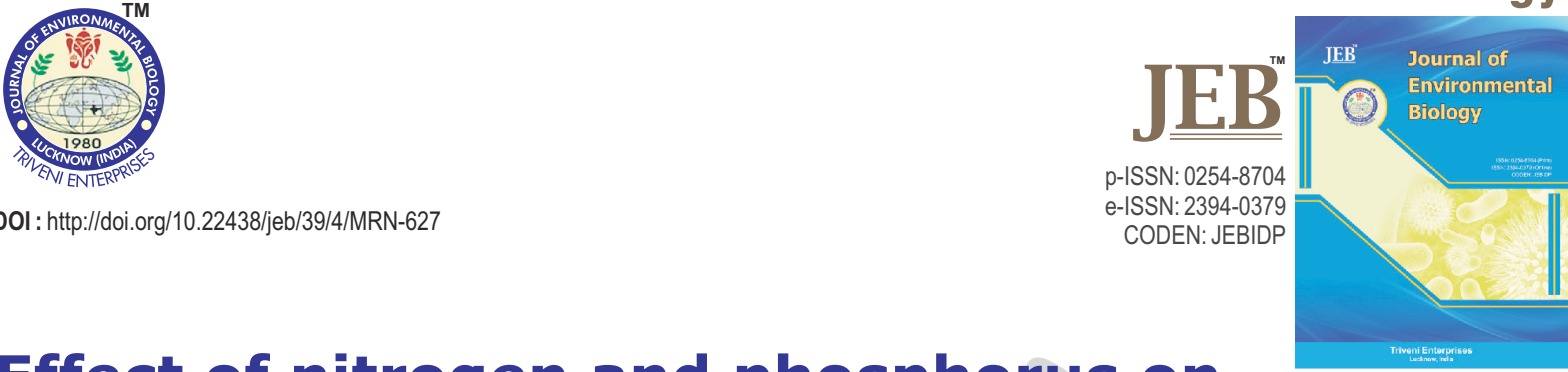

\title{
Effect of nitrogen and phosphorus on growth and microcystin production in three Microcystis species
}

Authors Info

K.L. Lee', K.Y. Jung', J.H. Kim, Y.S. $\mathrm{Kim}^{3}$ and H.S. Kim ${ }^{3 *}$

'Watershed Ecology Research Team, National Institute of Environmental Research, Incheon, 22689, South Korea

${ }^{2}$ Nakdong River Environment Research Center, National Institute of Environmental Research, Gyeongsangbuk-do, 40103, South Korea

${ }^{3}$ Department of Biology, Kyungpook National University, Daegu, 41566, South Korea

${ }^{4}$ Microorganism Resources Division, National Institute of Biological Resources, Incheon, 22689, South Korea

*Corresponding Author Email : kimhsu@knu.ac.kr

Key words

Cyanobacterial blooms Freshwater ecosystem Microcystin

Microcystis species

Nitrogen \& Phosphorus

Publication Info

Paper received : 08.04.2017

Revised received: 13.07.2017

Re-revised received: 06.09.2017

Accepted : 29.09.2017

\section{Abstract}

Aim : The effects of nitrogen and phosphorus concentration on growth and microcystin production were investigated in three species of bloom-forming Microcystis isolated from two South Korean freshwater systems.

Methodology : Three species of cyanobacteria were collected from Yeongchun Dam and Ankei Dam in Kyungpook Province, South Korea. Culture experiments were conducted at $25 \pm 1{ }^{\circ} \mathrm{C}$ under cool white fluorescent light (ca. $50 \mu \mathrm{mol} \mathrm{m}^{-2} \mathrm{~s}^{-1}$ ) in media with different concentrations of nitrogen ( 0 to $20 \mathrm{mg} \mathrm{l}^{-1}$ ) and phosphorus $\left(0\right.$ to $\left.5 \mathrm{mg} \mathrm{l}^{-1}\right)$. Cell numbers were determined in a hemocytometer for calculation of growth rate Microcystin was analysed using high pressure liquid chromatography.

Results : The highest growth rate $\left(\mu_{\max }\right)$ and maximal microcystin production occurred at nitrogen concentrations of 10 and $20 \mathrm{mg} \mathrm{l}^{-1}$ in all three species. The response to phosphorus concentration was more complex. The highest growth rate $\left(\mu_{\max }\right)$ of $M$. aeruginosa, $M$. ichthyoblabe and $M$. viridis occurred at phosphorus concentrations of $0.5 \mathrm{mg} \mathrm{l}^{-1}, 0.1 \mathrm{mg} \mathrm{l}^{-1}$, and $3 \mathrm{mg} \mathrm{l}^{-1}$, respectively. M.aeruginosa also had maximal microcystin production at $0.5 \mathrm{mg}^{-1} \mathrm{P}$. In contrast, $M$.ichthyoblabe and $M$. viridis had high microcystin production at $0 \mathrm{mgl}^{-1}$ and at $5 \mathrm{mgl}^{-1} \mathrm{P}$ (the highest tested concentration), and low microcystin production at $0.1 \mathrm{mgl}^{-1} \mathrm{P}$. Thus at $0.1 \mathrm{mgl}^{-1}$, M.ichthyoblabe had the highest growth rate but produced least amount of microcystin. The types of microcystins produced varied according to species and nutrient conditions.

Interpretation : Microcystin production and growth in Microcystis species isolated from South Korea varied according to species and nutrient conditions. These species responded similarly to different nitrogen concentrations, but differently to different phosphorus concentrations.

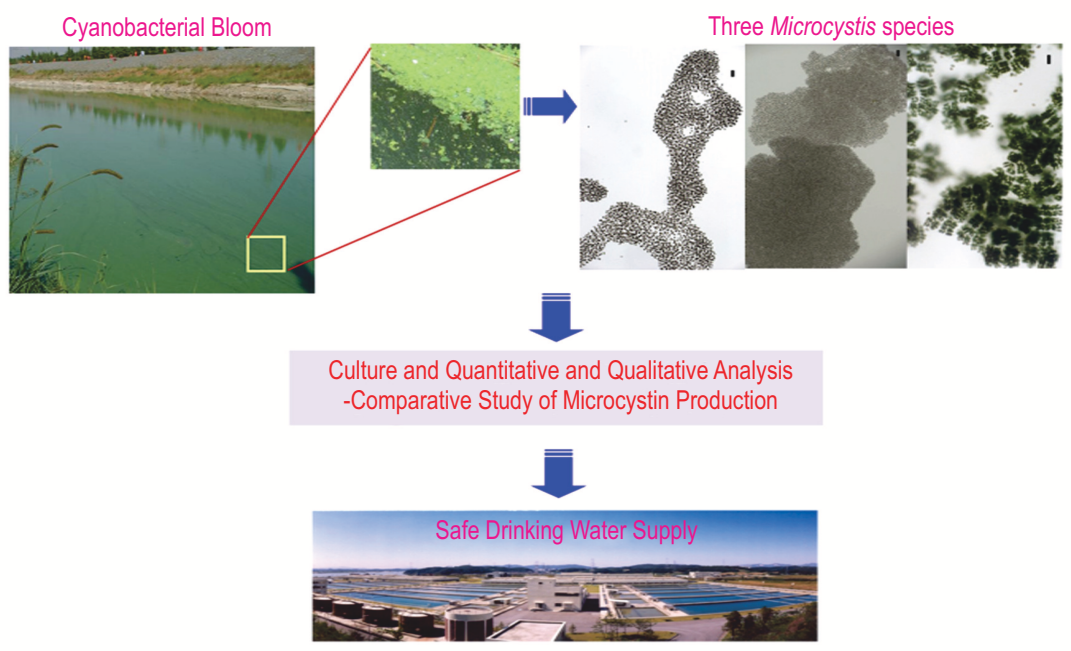




\section{Introduction}

Cyanobacterial blooms are common in water bodies all over the world, and cyanobacterial toxins are a serious threat to the health of aquatic animals and humans. Microcystins are hepatotoxins produced by certain freshwater cyanobacteria and have well-documented harmful effects in humans (KuiperGoodman et al., 1999; Falconer, 2001). Microcystis, Anabaena, Oscillatoria, Nostoc and Anabaenopsis can produce microcystins (Kaebernick and Neilan, 2001) and species of the genus Microcystis are the best-known microcystin-producing cyanobacteria (Park et al. 1998; Kurmayer et al., 2002; ViaOrdorika et al., 2004; Ozawa et al., 2005; Znachor et al., 2006). The genus Microcystis consists of 15 species, including $M$. aeruginosa, $M$. ichthyoblabe, $M$. flos-aquae, $M$. novacekii, $M$. viridis and $M$. wesenbergii, all of which have characteristic cell and colony morphologies (Komárek and Anagnostidis, 1999).

Microcystin production is species- and strain-specific (Oh et al., 2000; Rohrlack et al., 2001; Kurmayer et al., 2002; ViaOrdorika et al., 2004; Yéprémian et al., 2007). Thus, different species and strains produce different type and amount of microcystins, depending on environmental conditions. Studies carried of microcystin production, have mainly focused on Microcystis aeruginosa (Codd and Poon, 1998; Watanabe, 1996; Oh et al., 2000). However, M. ichthyoblabe and M. viridis are also responsible for Microcystis blooms (Park et al., 1998; Sabour et al., 2002).

It is necessary to understand the physiological and ecological characteristics of microcystin production by different species of Microcystis to better ensure a safe supply of drinking water. Nevertheless, only few studies have compared microcystin production using cultures of different Microcystis species and there are no data on the growth of Korean strains of Microcystis in culture. In this study, the authors investigated the effects of nitrogen and phosphorus on the growth and microcystin production of three species of bloom-forming Microcystis ( $M$. aeruginosa, $M$. ichthyoblabe and $M$. viridis) that were isolated from Korean freshwater systems and grown in culture.

\section{Materials and Methods}

Strain isolation : Three species of Microcystis (M. aeruginosa YC, M. ichthyoblabe AK and $M$. viridis AK) were isolated from Youngcheon dam and Ankei dam during cyanobacterial blooms. These dams are adjacent and linked by a number of waterways. The species composition of the cyanobacterial communities in two dams were similar at the time of blooms.

Culture conditions : All culture experiments were conducted using CB medium (Watanabe, 1996). Unialgal stock cultures were established and maintained in $\mathrm{CB}$ medium (buffered to $\mathrm{pH}$ 9.0 with carbon free $\mathrm{NaOH}$ ) at $25 \pm 1^{\circ} \mathrm{C}$ and a light intensity of approximately $50 \mu \mathrm{mol} \mathrm{m}^{-2} \mathrm{~s}^{-1}$ under continuous cool white fluorescent light. For nutrient experiments, clones selected from the stock cultures at the exponential growth phase were first adapted to nutrient-depleted medium (no Nor P) for one week, and were then inoculated (initial cell density: ca 5000 cells) into medium with different levels of nitrogen $\left(0,1,3,5,10,20 \mathrm{mg} \mathrm{l}^{-1}\right)$ and phosphorus $\left(0,0.1,0.5,1,3,5 \mathrm{mg} \mathrm{l}^{-1}\right)$. $\mathrm{NO}_{3}^{-}$and $\mathrm{PO}_{4}^{3-}$ were the sources of nitrogen and phosphorus. These cultures were grown for two weeks as described above. Experiments were conducted in triplicate and cell numbers were determined with a hemocytometer following sonication $(30 \mathrm{~W}, 10 \mathrm{sec}$; Fisher Scientific, USA). Growth rate was calculated as $\mu=\left(\ln N_{2}-\ln N_{1}\right)$ / $\left(t_{2}-t_{1}\right)$, where $N_{2}$ and $N_{1}$ are the number of cells during the period of exponential growth at time $t_{2}$ and $t_{1}$.

Analysis of microcystins : High-pressure liquid chromatography (HPLC) was used to identify and quantify the microcystins. For this analysis, $100 \mathrm{ml}$ of culture was filtered through a $0.45-\mu \mathrm{m} \mathrm{GF} / \mathrm{C}$ filter (Whatman, USA) and then lyophilized for $24 \mathrm{hrs}$ in a freeze-drier (Labconco, USA). The lyophilized samples were extracted three times with $50 \mathrm{ml}$ of $5 \%(\mathrm{v} / \mathrm{v})$ acetic acid for $30 \mathrm{~min}$, while being homogenized with an ultrasonicator (Fisher Scientific, USA).The extract was then centrifuged at $4000 \times \mathrm{g}$ for $15 \mathrm{~min}$, and the supernatant was applied to a Sep-Pak C18 cartridge (Waters, USA) that was preactivated by washing with $10 \mathrm{ml}$ of $100 \%$ methanol and $10 \mathrm{ml}$ of HPLC-grade distilled water. The cartridge column was washed with $20 \%$ methanol and bound microcystins were eluted with $10 \mathrm{ml}$ of $0.1 \%$ trifluoroacetic acid in methanol. The eluate was evaporated in a freeze drier (Labconco, USA), and the residue was dissolved in $100 \%$ methanol. The solution was then separated by HPLC using an Xterra- $\mathrm{C}_{18}$ column ( $5 \mu \mathrm{m} ; 4.6 \times 15 \mathrm{~cm}$; Waters) and a mobile phase of $52 \%$ methanol and $48 \% 0.05 \mathrm{M}$ phosphate buffer $(\mathrm{pH} 3.0)(\mathrm{v} / \mathrm{v})$ at a flow rate of $1 \mathrm{ml} \mathrm{min}^{-1}$. Microcystins were detected by measuring the absorbance at $210-420 \mathrm{~nm}$ using a photodiode array (Waters, USA).

\section{Results and Discussion}

Fig. 1 shows the effects of nitrogen concentration on the growth rate and microcystin production ( $\mathrm{mg} \mathrm{g}^{-1}$ d.wt.) in $M$. aeruginosa YC, M. ichthyoblabe AK and $M$. viridis AK. All three species had maximal growth rates and maximal microcystin production at nitrogen concentrations of 10 to $20 \mathrm{mg} \mathrm{l}^{-1}$.

The specific types of microcystin produced varied according to species and nitrogen concentration. Thus, $M$. aeruginosa $Y C$ produced microcystin-YR (MC-YR) when grown in 1-20 mg l-1 nitrogen, but also produced microcystin-RR (MC-RR) and microcystin-LR (MC-LR) when grown in 10-20 $\mathrm{mg} \mathrm{I}^{-1} \mathrm{~N}$. M. ichthyoblabe AK produced MC-YR when grown in 0-10 $\mathrm{mg} \mathrm{l}^{-1}$ nitrogen, but produced MC-RR and MC-LR when grown in $20 \mathrm{mg} \mathrm{l}^{-1}$ nitrogen $M$. viridis AK produced mostly MC-RR and MC-LR when grown in 3-20 $\mathrm{mg} \mathrm{l}^{-1}$ nitrogen but produced very little MC-YR at these nitrogen concentrations.

Fig. 2 shows the effects of $P$ concentration on the growth rate and microcystin production of these three Microcystis 

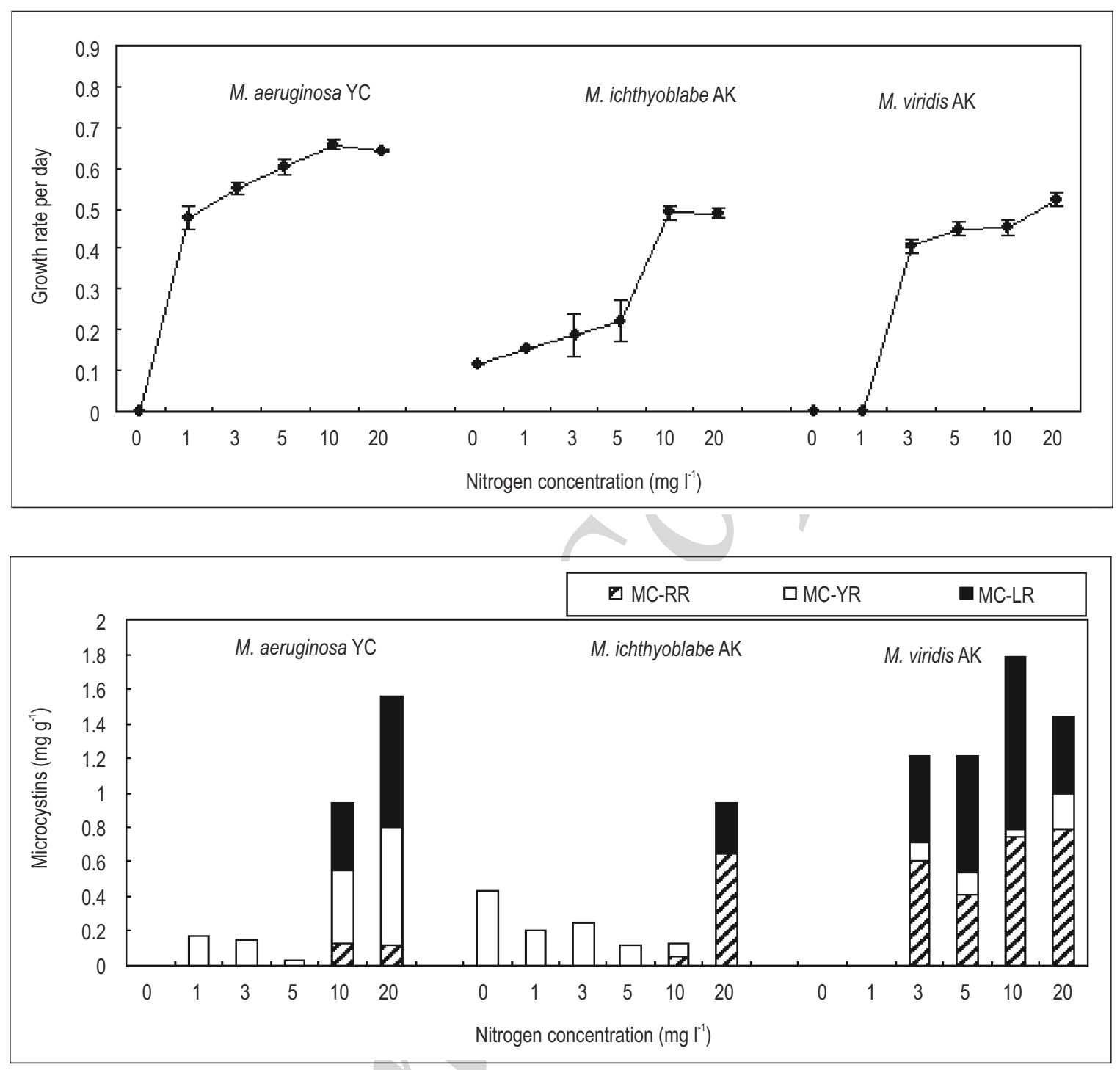

Fig. 1 : Effect of nitrogen on growth rate (top) and microcystin production (bottom) in three Microcystis morphospecies

species. M. aeruginosa YC had maximal growth rate and microcystin production at $0.5 \mathrm{mg} \mathrm{l}^{-1}$. M. ichthyoblabe AK had maximal growth rate at $0.1 \mathrm{mg} \mathrm{l}^{-1}$ phosphorus and growth rate decreased gradually as phosphorus concentration increased to 5 $\mathrm{mg} \mathrm{l}^{-1}$. In contrast, M. ichthyoblabe AK produced maximal microcystin at $0 \mathrm{mg} \mathrm{l}^{-1}$ and $5 \mathrm{mg} \mathrm{l}^{-1}$ phosphorus, but minimal microcystin at $0.1 \mathrm{mg} \mathrm{l}^{-1}$ phosphorus Thus, M. ichthyoblabe AK produced more microcystin at phosphorus concentrations that led to lower growth rate.

The growth rate of $M$. viridis AK increased with increasing phoshphorus concentration up to $3 \mathrm{mg} \mathrm{I}^{-1}$ and then decreased slightly; its maximum microcystin production was at $0 \mathrm{mg} \mathrm{l}^{-1}$ and 5 $\mathrm{mg} \mathrm{I}^{-1}$ phosphorus (as with M. ichthyoblabe AK). Interestingly, although this species did not grow at $0 \mathrm{mg} \mathrm{l}^{-1}$ phosphorus, it produced abundant microcystin under this condition. $M$. aeruginosa YC produced all three types of microcystin (MC-RR, MC-YR and MC-LR), but M. ichthyoblabe and M. viridis only produced two detectable microcystins (MC-RR and MC-LR). M. aeruginosa $\mathrm{YC}$ produced MC-RR at all tested phosphorus concentrations, and produced the most MC-RR when grown in 0.5 to $5 \mathrm{mg} \mathrm{l}^{-1}$ P. M. ichthyoblabe AK also produced MC-RR at all tested phosphorus concentrations, but the concentration of MC$\mathrm{LR}$ was only significant at $5 \mathrm{mg} \mathrm{l}^{-1} \mathrm{P}$. M. viridis AK produced MC$\mathrm{RR}$ at all tested concentrations, but produced nearly similar amount of MC-LR at all tested concentrations. 

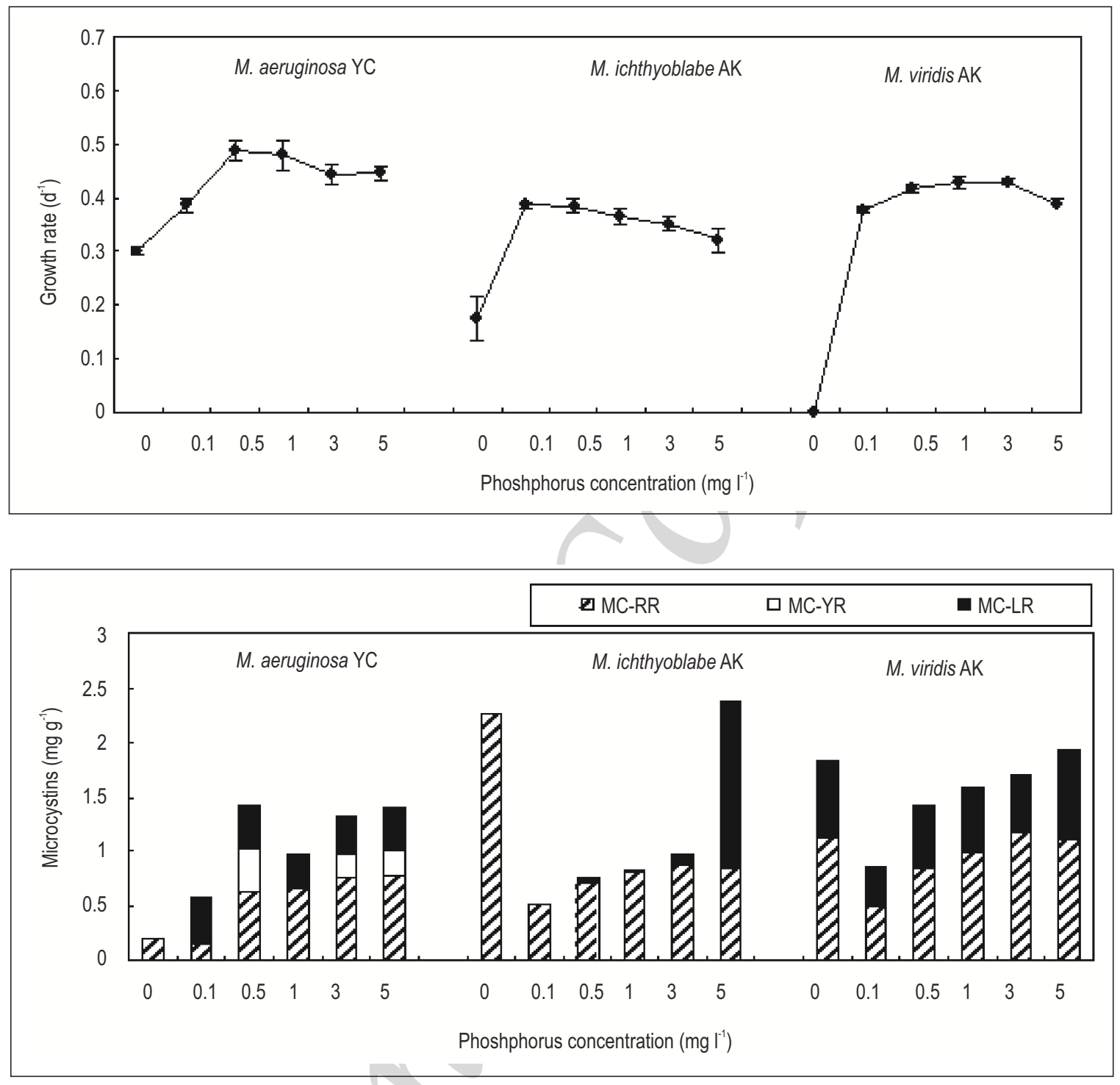

Fig. 2 : Effect of phosphorus on growth rate (top) and microcystin production (bottom) in three Microcystis morphospecies

Previous studies have reported that nitrogen concentration affects the production of intracellular microcystins in Microcystis, and most of these studies have reported positive correlation between microcystin production and nitrogen concentration (Codd and Poon, 1998; Lee et al., 2000), in agreement with the results of this study. In particular, the results on $M$. aeruginosa $Y C$ were similar to those of Codd and Bell (1996), who reported that maximal microcystin production occurred at high nitrogen concentrations. Sivonen (1990) also reported that the microcystin levels of a non-N-fixing Oscillatoria strain increased as nitrogen concentration increased. However, Rapala et al. (1997) found that maximum microcystin production in $\mathrm{N}$-fixing Anabaena strain occurred in nitrogen depleted conditions. Non $\mathrm{N}$-fixing cyanobacteria, such as Microcystis and certain types of Oscillatoria, may require nitrogen for microcystin formation simply because microcystins are nitrogen containing heptapeptide molecules (Sivonen, 1990; Giani et al., 2005).

The results suggest that an increased nitrogen concentration in freshwater systems may promote growth and microcystin production by non- $\mathrm{N}$-fixing toxic cyanobacteria. In agreement, previous field studies have reported positive correlation between nitrogen concentration, cyanobacterial biomass and microcystin content (Downing et al., 2001; Giani et al., 2005). All three species of Microcystis produced MC-RR and MC-LR at the highest tested nitrogen concentrations $\left(10-20 \mathrm{mgl}^{-1}\right)$. These results 
are similar to those of Hesse and Kohl (2001), who reported that high concentrations of MC-RR and MC-LR occurred when Microcystis grows under nitrogen-rich conditions.

There have been conflicting results on the effect of phosphorus on microcystin production in different cyanobacterial species. Some previous studies of various Microcystis strains have reported that phosphorus concentration had little impact on microcystin production (Codd and Poon, 1998; Song et al., 1998). Conversely, microcystin production by Anabaena (Rapala et al., 1997) and O. agardhii (Sivonen, 1990) increases with phosphorus concentration under phosphorus-limited conditions. Recently, Oh et al. (2000) reported that phosphorus-limiting conditions reduced the growth but increased microcystin content in $M$. aeruginosa. In the present study, it was found that microcystin production by $M$. aeruginosa $Y C$ increased with growth rate when the phosphorus concentration was $0-0.5 \mathrm{mg} \mathrm{l}^{-1}$, but additional phosphorus had little or no effect on either parameter. These results are consistent with those of Sivonen (1990), who reported that toxin production by O. agardhii increases as phosphorus concentration increases under phosphorus-limited conditions (0.1-0.4 $\left.\mathrm{mg} \mathrm{l}^{-1}\right)$. Thus, optimal growth and microcystin production in $M$. aeruginosa $Y C$ seem to occur at the same range of phosphorus concentrations. In contrast, maximal microcystin production in $M$. ichthyoblabe AK and $M$. viridis AK occurred at phosphorus concentrations that had the lowest growth rates.

Observations regarding growth and microcystin production in phosphorus depleted conditions could have been affected by incomplete removal of phosphorus that accumulated in cells prior to the experiments. This could explain why microcyst in production in M. ichthyoblabe AK and M. viridis AK was greatest under conditions of environmental stress ( $P$ depletion) and when the growth rate was lowest. However, Hesse and Kohl (2001) reported that production of MC-RR and MC-LR in various strains of $M$. aeruginosa increased in phosphorus-limited conditions. Oh et al. (2000) also reported that the ratio of MC-LR to MC-RR in M. aeruginosa increased under phosphorus-limited conditions, and that this species produced no detectable MC-YR. The results of $M$. aeruginosa $Y C$ indicated that this species produced more MCRR than other MC variants, MC-RR production increased with phosphorus concentration, and phosphorus had little effect on production of MC-LR and MC-YR. M. ichthyoblabe AK produced maximal MC-RR in phosphorus-depleted medium, but produced maximal MC-LR at the highest tested concentration of phosphorus $\left(5 \mathrm{mg} \mathrm{l}^{-1}\right)$. The production of MC-RR in $M$. ichthyoblabe AK was relatively high at all tested phosphorus concentrations.

The effect of different environmental conditions on toxin production differs among cyanobacteria species. Oscillatoria agardhii produces more toxins under conditions that support optimal growth (Sivonen, 1990), but the conditions that support optimal growth in $M$. aeruginosa and $M$. viridis do not support optimal toxin production (Watanabe and Oishi, 1985; Song et al., 1998). As described above, we found significant speciesspecific responses for microcystin production under different phosphorus concentrations, but not for different nitrogen concentrations. The findings of this study are thus in agreement with the previous studies (Park et al., 1998; Ozawa et al., 2005), which reported that microcystin production varied according to the composition of Microcystis species where cyanobacterial blooms occur. In addition, differences in microcystin production among species depend on physiological and ecological responses to multiple environmental factors (Rohrlack et al., 2001; Yéprémian et al., 2007).

In conclusion, the results of the present study show that nutrient levels influence growth and microcystin production in three bloom-forming Microcystis species native to Korea, and that nutrient levels have different effects on different species. Further, qualitative and quantitative investigations of cyanobacteria species are needed to improve the management of drinking water supplies that are affected by toxic cyanobacteria, such as Microcystis.

\section{Acknowledgments}

The authors would like to thank the anonymous reviewers for their valuable comments and suggestions which helped to revise and improve the manuscript.

\section{References}

Codd, G.A. and G.K. Poon : Cyanobacterial toxins. In : Biochemistry of Algae and Cyanobacteria (Eds. : L.J. Roger and J.R. Gallon). Oxford University Press, Oxford, pp. 283-296 (1998).

Codd, G.A. and S.G. Bell : The occurrence and fate of blue-green algal toxin in freshwaters. National Rivers Authority, R and D Report, London, UK (1996).

Downing, J.A., S.B. Watson and E. McCauley: Predicting cyanobacteria dominance in lakes. Can. J. Fish. Aquat. Sci., 58, 1905-1908 (2001).

Falconer, I.R.: Toxic cyanobacterial bloom problems in Australian waters, risk and impacts on human health. Phycologia, 40, 228-233 (2001).

Giani, A., D.F. Bird, Y.T. Prairie and J.F. Lawrence : Empirical study of cyanobacterial toxicity along a trophic gradient of lakes. Can. J. Fish Aquat. Sci., 62, 2100-2109 (2005).

Hesse, K. and J.G. Kohl : Effects of light and nutrient supply on growth and microcystin content of different strains of Microcystis aeruginosa. In : Cyanotoxins - occurrence, causes, consequences (Ed.: I. Chorus). Springer-Verlag, Berlin, pp. 104-115 (2001).

Kaebernick, M. and B.ANeilan : Ecological and molecular investigations of cyanotoxin production. FEMS Microbiol. Ecol., 35, 1-9 (2001).

Komárek, J. and K. Anagnostidis : Cyanoprokaryota 1.Teil : Chroococcales. In : Süßwasserflora von Mitteleuropa (Eds.: H. Ettl,G. Gärtner, H. Heynig and D. Mollenhauer). Spektrum Akademischer Verlag, Heidelberg, pp. 224-236 (1999).

Kuiper-Goodman, T., I. Falconer and J. Fitzgerald: Human health aspects. In : Toxic cyanobacteria in water : A guide to their public health consequences, monitoring and management (Eds. : I. Chorus and J. Bartram). E \& FN Spon, London, pp. 112-153 (1999). 
Kurmayer, R., E. Dittmann, J. Fastner and I. Chorus: Diversity of microcystin genes within a populaton of the toxic cyanobacterium Microcystis spp. in Lake Wannsee (Berlin, Germany). Microb. Ecol., 43, 107-118 (2002).

Lee, S.J., M. H. Jang, H.-S.Kim, B. D. Yoon and H. M. Oh : Variation of microcystin content of Microcystis aeruginosa relative to medium $\mathrm{N}$ : P ratio and growth stage. J. Appl. Phycol., 89, 323-329 (2000).

Oh, H. M., S.J. Lee, M. H. Jang and B. D. Yoon : Microcystin production by Microcystis aeruginosa in a phosphorus-limited chemostat. Appl. Environ. Microbiol., 66, 176-179 (2000).

Ozawa, K., H. Fujioka, M. Muranaka, A. Yokoyama, Y. Katagami, T. Homma, K. Ishikawa, S. Tsujimura, M. Kumagai, M.F. Watanabe and H. D. Park: Spatial distribution and temporal variation of Microcystis species composition and microcystin concentration in Lake Biwa. Environ. Toxicol., 20, 270-276 (2005).

Park, H.D., C. Iwami, M.F. Watanabe, K.I.Harada, T. Okino and H. Hayashi: Temporal variabilities of the concentrations of intra and extracellular microcystin and toxic Microcystis species in a hypertrophic lake, Lake Suwa, Japan (1991-1994). Environ. Toxicol. Water Qual.,13,61-72 (1998).

Rapala, J., K. Sivonen, C. Lyra and S.I. Niemelä: Variation of microcystins, cyanobacterial hepatotoxins in Anabaena spp. as a function of growth stimuli. Appl. Environ. Microbiol., 63, 2206-2212 (1997).

Rohrlack, T., M. Henning and J.G.Kohl : Isolation and characterization of colony-forming Microcystis aeruginosa strains. In : Cyanotoxins occurrence, causes, consequences (Ed.: I. Chorus). SpringerVerlag, Berlin, pp. 152-158 (2001).

Sabour, B., M. Loudiki, B. Oudra, V. Vasconcelos, R. Martins, S. Oubraim and B. Fawzi :Toxicology of a Microcystis ichthyoblabe water bloom from Lake Oued Mellah (Morocco). Environ. Toxicol., 17, 24-31 (2002)

Sivonen, K.: Effects of light, temperature, nitrate, orthophosphate, and bacteria on growth and hepatotoxin production by Oscillatoria agardhii strains. Appl. Environ. Microbiol., 56, 2658-2666 (1990).

Song, L., T. Sano, R. Li, M.M. Watanabe, Y. Liu and K. Kaya : Microcystin production of Microcystis viridis (cyanobacteria) under different culture conditions. Phycol. Res., 46,19-23 (1998).

Via-Ordorika, L., J. Fastner, R. Kurmayer, M. Hisbergues, E. Dittmann, J. Komárek, M. Erhard and I. Chorus : Distribution of microcystinproducing and non-microcystin-producing Microcystis sp. in European freshwater bodies: Detection of microcystins and microcystin genes in individual colonies. System. Appl. Microbiol., 27, 592-602 (2004).

Watanabe, M.F.: Production of microcystins. In: Toxic Microcystis (Eds.: M.F. Watanabe, K.I. Harada, W.W. Carmichael and H. Fujiki). CRC Press, Boca Raton, pp.35-56 (1996).

Watanabe, M.F. and S. Oishi : Effects of environmental factors on toxicity of a cyanobacterium (Microcystis aeruginosa) under culture conditions. Appl. Environ. Microbiol., 49, 1342-1344 (1985).

Znachor, P., T. Jurczak, J. Komárková, J. Jezberová, J. Mankiewicz, K. Kaštovská and $E$. Zapomělová : Summer changes in cyanobacterial bloom composition and microcystin concentration in eutrophic Czech reservoirs. Environ. Toxicol., 21, 236-243 (2006).

Yéprémian, C., M.F. Gugger, E. Briand, A. Catherine, C. Berger, C. Quiblier and C. Bernard: Microcystin ecotypes in a perennial Planktothrix agardhii bloom. Water. Res., 41, 4446-4456 (2007). 